\title{
AMERIGO VESPUCCI VERSUS CLAUDE LÉVI-STRAUSS: WHO IS THE BEST SEA WORLD ANTHROPOLOGIST?
}

\author{
Derya AGİş
}

\author{
Ph.D. student, Ankara University, Institute of Socal Sciences, Western Lan- \\ guages and Literatures, Department of Italian Language and Literature, \\ e-mail.fdagis@ankara.edu.tr E deryaagis@gmail.com
}

\section{ABSTRACT}

\section{Keywords:}

Environmental humanities, ecological history, Amerigo Vespucci, structural anthropology, Claude Lévi-Strauss, South America

\section{Anahtar kelimeler: Çevreci beşerî bil- imler, ekolojik tarih, Amerigo Vespucci, yapisal antropoloji, Claude Lévi-Strauss, Güney Amerika}

Amerigo Vespucci (1454-1512) wrote letters for depicting his four sea voyages to the Americas, thus 'the New World': he talked about the primitiveness of the natives, the animals specific to the region, and the plants that were used as foods or medicines by the natives in his letters to traders, politicians, family members, and navigators. Besides, Claude Lévi-Strauss (1908-2009) talked about different natives from some tropical regions in his work entitled Tristes tropiques (1955; A World on the Wane); moreover, he wrote Le Totémisme aujourd'hui (1962; Totemism) and Mythologiques in four volumes: Le Cru et le cuit (1964; The Raw and the Cooked), Du miel aux cendres (1966; From Honey to Ashes), L'Origine des manières de table (1968; The Origin of Table Manners), and L'Homme nu (1971; The Naked Man). As Vespucci depicted naked natives, their lack of a legal system, cures, totems, and eating habits as well as the status of native women in their societies, just like Lévi-Strauss, he might seem to have influenced Lévi-Strauss and the formation of structural anthropology. Consequently, this paper will compare Vespucci's sixteenth century popular ethnographic descriptions to Lévi-Strauss's twentieth century structural anthropological analyses.

\section{AMERIGO VESPUCCI CLAUDE LÉVI-STRAUSS'A KARŞI: KİM EN IYYİ DENIZZ DÜNYASI ANTROPOLOĞU?}

\author{
ÖZ
}

Amerigo Vespucci (1454-1512) `Yeni Dünya’ olarak bilinen Amerika kıtasına dört deniz yolculuğu gerçekleştirmiştir. Bu yolculuklar hakkında tüccarlara, politikacılara, aile üyelerine ve denizcilere mektuplar yazmıştır. Bu mektuplarda yerlilerin ilkellliklerinden, Amerika kıtasına özgü hayvanlardan ve bu kıtada yaşayan yerlilerin yemek ya da ilaç olarak kullandıkları bitkilerden söz etmiştir. Claude Lévi-Strauss (1908-2009) ise Tristes tropiques (1955; [Üzgün Tropikler]) adlı eserinde tropikal bölgelerde yaşamakta olan yerlileri tasvir etmiştir. Lévi-Strauss' un Le Totémisme aujourd'hui (1962; [Günümüzde Totemizm]) ve Mythologiques adlı iki adet kitabı da vardır. Mythologiques adlı eseri dört farklı seriden oluşur: Le Cru et le cuit (1964; [Ham ve Pişmiş]), Du miel aux cendres (1966; [Baldan Küllere]), L'Origine des manières de table (1968; [Sofra Adabının Kökeni]) ve L'Homme nu (1971; [Çıplak Adam]). Lévi-Strauss gibi Vespucci de yerlilerin giysilerinin ve hukuki sistemlerinin olmayışını, kadınların yerliler arasındaki konumunu, yerlilerin ilaçlarını, totemlerini ve yemek yeme alışkanlıklarını anlattığından Lévi-Strauss'u ve yapısal antropolojinin oluşumunu etkilemiş gibi görünebilir. Bu çalışma, Vespucci'nin 16. yüzyılda kaleme aldığ1 popüler etnografik tasvirlerini Lévi-Strauss'un 20. yüzyılda yaptığ1 yapısal antropolojik analizleri ile kıyaslar. 


\section{INTRODUCTION}

This paper deals with the letters Amerigo Vespucci (1454-1512) wrote for depicting his voyages to the Americas and compares the descriptions of Indians in them to those in the works of Claude Lévi-Strauss (1908-2009). Vespucci was a Florentine trader; Lorenzo the Magnificient used to be the ruler of Florence between 1469 and 1492, the year in which he passed away (Fernández-Armesto, 2007: 14). The Medici family was so sacred to be associated with the "astrologer-kings who followed Christ's star to Bethlehem" (Fernández-Armesto, 2007: 14). Amerigo had an extended Italian family (Fernández-Armesto, 2007 15). Lorenzo dei Medici's brother Giuliano dei Medici was supposed to be in love with his cousin-in-law Simonetta Vespucci (Fernández-Armesto, 2007: 16). Therefore, Amerigo Vespucci's family had well-known, prosperous, and rich connections. Amerigo Vespucci's father and his oldest brother were notaries; Amerigo received his education and instruction from his uncle, called Giorgio Antonio: he was trained in poetry, history, philosophy, astronomy, and astrology (Fernández-Armesto, 2007: 20). Florentines had learned about geography through Ptolemy's work titled Geography since approximately 1397; Amerigo Vespucci's interest in geography derives from this book (Fernández-Armesto, 2007: 21).

Regarding his voyages, he departed twice on behalf of Spain, and twice on behalf of Portugal: "on May 10, 1497, he embarked on his first journey, departing from Cadiz with a fleet of Spanish ships ... the ships sailed through the West Indies and made their way to the mainland of Central America within approximately five weeks"; he might have discovered Venezuela and returned to Cadiz in October 1498 ("Amerigo Vespucci," 2017).

In May 1499, he passed through the equator, saw Guyana, and explored the Brazilian coasts by discovering the Amazon River and Cape St. Augustine ("Amerigo Vespucci," 2017).

On May 14, 1501, Amerigo Vespucci went to Cape Verde for Portugal; he visited South America by sailing "from Cape São Roque to Patagonia" ("Amerigo Vespucci," 2017). Accordingly, he found Rio de Janeiro and Rio de la Plata ("Amerigo Vespucci," 2017).

On June 10, 1503, Amerigo Vespucci and Gonzal Coelho traveled again to Brazil; Amerigo Vespucci discovered Bahia and the island of South Georgia during this voyage ("Amerigo Vespucci," 2017).
Besides, Claude Lévi-Strauss (1908-2009) was a "French social anthropologist" who inserted structuralism into the field of anthropology for analyzing "cultural systems (e.g., kinship and mythical systems) in terms of the structural relations among their elements" (The Editors of Encyclopædia Britannica, 2016). He studied philosophy and law at the University of Paris, was a teacher in a secondary school, worked as a professor of sociology at the University of São Paulo, Brazil from 1934 through 1937, while conducting fieldwork with the Brazilian Indians; he became the chair of the social anthropology department at the Collège de France in 1959 (The Editors of Encyclopædia Britannica, 2016).

The data of this research are from the following works by Amerigo Vespucci and Claude Lévi-Strauss: on the one hand, Amerigo Vespucci wrote nine letters -about his voyages to the Americas and to the Brazilian coasts- that can be found in the following book:

Vespucci, Amerigo. Cronache Epistolari: Lettere 1476-1508. Compiler: Leandro Perini. Florence: Firenze University Press, 2013.

Amerigo Vespucci's letters in the book are listed below:

Amerigo Vespucci's letter to his father Mr. Anastagio Vespucci in Florence from Trebbio del Mugello written on October 19, 1476 (pages: 3-4);

Amerigo Vespucci's letter to the commissar of the duke of Mantua in Genova from Seville written on December 30, 1492 (page 87);

Amerigo Vespucci's letter to Lorenzo di Pierfrancesco dei Medici from Seville written on July 28, 1500 (pages: 88-101);

Amerigo Vespucci's letter to Lorenzo di Piefrancesco dei Medici from Capo Verde on June 4, 1501 (pages: 102-108);

Amerigo Vespucci's letter to Lorenzo di Pierfrancesco dei Medici from Lisbon written in 1502 (pages: 109-113);

Amerigo Vespucci's letter written probably in 1502 to an anonymous Florentine (pages: 114-119);

Amerigo Vespucci's letter to Lorenzo di Pierfrancesco dei Medici from Lisbon in 1502-1503. This letter is recognized as "Mundus Novus" [New World] (pages: 120-135); 
Amerigo Vespucci's letter to Pier Soderini from Lisbon on September 4, 1504 (pages: 136-165); and

Amerigo Vespucci's letter to Cardinal Francisco Jiménez de Cisneros from Seville on December 9, 1508 (pages: 166-168).

On the other hand, Claude Lévi-Strauss wrote the following books about Brazilian Indians: a) Tristes tropiques (1955; A World on the Wane); b) Le Totémisme aujourd'hui (1962; Totemism), and c) Mythologiques in four volumes: 1) Le Cru et le cuit (1964; The Raw and the Cooked), 2) Du miel aux cendres (1966; From Honey to Ashes), 3) L'Origine des manières de table (1968; The Origin of Table Manners), and 4) L'Homme nu (1971; The Naked Man).

This study differs from my previous study: Agiş, Fazıla Derya. "Peace Education, Environmentalism, and Amerigo Vespucci". İdil 6.38 (2017): 2673-2684, since it compares descriptions of the Indians in Amerigo Vespucci's letters to those in the works written by Claude Lévi-Strauss, a structural anthropologist within the framework of structuralism, thus structural anthropology.

\section{Method and Theoretical Framework: Structu- ral Anthropology}

The theory of structural anthroropology developed by Claude Lévi-Strauss is chosen for analyzing both Amerigo Vespucci's letters and the works of Claude Lévi-Strauss. This theory posits that cultural practices constitute systems among which one can cite narrating mythologies, forming kinship structures, cooking and serving food, and using languages; these systems are based on mental stuctures, or patterns, thus on ways of thinking of populations that can be universal (The Editors of Encyclopædia Britannica, 2014). Accordingly, structuralism derives from Gestalt psychology (Gestaltism) where patterns, thus parts of an object are smaller than the whole object, which should be taken into account totally (Briggs and Meyer, 2009). In linguistics, as Ferdinand de Sausssure suggested in the late 1920s, there are grammatical rules that the speakers of these languages employ implicitly; these rules form the whole language from a Gestalt-like perspective (Briggs and Meyer, 2009). In anthropology, similarly, certain cultural practices that certain populations are used to are parts of an entire culture that shall be depicted via binary oppositions, such as "hot-cold, male-female, culture-nature, and raw-cooked" (Briggs and Meyer, 2009).

Structural anthropologists intend to conceive the symbolic meanings of cultural practices that are so implicit and learned that they can be regarded as culture-specific, as Claude Lévi-Strauss proposed in his book titled Structuralism and Ecology, which was published in 1972 (Briggs and Meyer, 2009).

Therefore, in this study, Amerigo Vespucci's narrations about Indians will be analyzed in terms of binary oppositions as suggested by Claude Lévi-Strauss.

\section{Research Problem}

This study investigates the letters of Amerigo Vespucci and compares them to what Claude Lévi-Strauss suggested in terms of structural anthropology for answering the question if Amerigo Vespucci should be regarded as an ethnographer, or anthropologist alongside a voyager, geographer, and trader just like Claude LéviStrauss.

\section{Findings}

4. 1. Healthy Life Conditions, Eating Habits, Herbal Cures, and Meals: Raw-Cooked and Hot-Cold

Amerigo Vespucci narrated us that the Indians were extremely healthy in his letter to Lorenzo di Pierfrancsco dei Medici from Lisbon in 1502, talking about the freshness of air in South America:

"Regarding the suitability of the land, I say that this land is very pleasant, tepid, and healthy, because we went on our ways on this land during those weather conditions, and 10 months passed; none of us died, and few of us became ill. As I said before, the people live a very long time here, they do not become ill; they never catch plague; nor do they suffer from respiratority disorders; they die just for natural reasons, or for drowning" (Vespucci, 2013: 113; my translation).

As well, Claude Lévi-Strauss (1961: 96) talked about South American Brazilian Amazon forests, in a section titled "The New World":

"The forest differs from our own by reason of the contrast between trunks and foliage. The leafage is darker and its nuances of green seem related rather to the mineral than to the vegetable world, and among minerals nearer to jade and tourmalin than to emerald and chrysolite. On the other hand, the trunks, white or grey in tone, stand out like dried bones against the dark background of the leaves. Too near to grasp the forest as a whole, I concentrated on details. Plants were more abundant than those we know in Europe. Leaves and 
stalks seemed to have been cut out of sheet metal, so majestic was their bearing, so impervious, as it seemed, the splendid development of their forms. Seen from outside, it was as if Nature in those regions was of a different order from the Nature we know: more absolute in its presence and its permanence."

Amerigo Vespucci seems to be the precursor of Claude Lévi-Strauss, as he talked about a perfect nature and the warmish weather South America: warmish, or tepid weather conditions are healthy enough for human beings who may not bear the cold or hot weather. The nature is a resource for long healthy lives according to Amerigo Vespucci and Claude Lévi-Strauss. Sometimes Amerigo Vespucci mentioned the freshness of weather in South America in his letters; as did he in his letter to Lorenzo di Pierfrancesco dei Medici written between 1502 - 1503 from Lisbon:

"The weather there is very tepid and nice; as I learned from what they had narrated me, plague and illnesses caused by polluted air do not exist there; if people do not die due to violence, they live a very long time: the reason for this is the fact that the winds always blow from the South there, and the wind we call Eurus is similar to Aquilon for us"' (Vespucci, 2013: 132 - 133, my translation).

Eurus is the wind blowing from the Southeast, whereas Aquilon is the wind blowing from the North (see Perini in Vespucci, 2013: 124). Moreover, the women could live until they would have become onehundredfifty years old, rarely caught any illnesses, and used herbal cures for recovering from some illnesses in these South American coastal zones (Vespucci, 2013: 132). Heat was a way to recovery from common cold according to Amerigo Vespucci's Indians, as they would wash a person who had high fever with cold water and try to heal him by turning him around hot fire; they would not have eaten for three days, if they had been suffering from irregularities related to their blood flows, and they would use certain herbs to vomit in accordance with the letter that Amerigo Vespucci wrote to Pier Soderini on September 4, 1504 from Lisbon. Similarly, Claude LéviStrauss (1961: 156) underlined that Indian doctors would use "round stool, a head-dress of straw, a gourd-rattle covered with a cotton net, and an ostrich-feather ... to capture the tefos, or evil spirits, which were the cause of all illness" in the twentieth century, as he witnessed this.

Additionally, Claude Lévi-Strauss discussed the uses of some fruits for taking revenge by Brazilian Bororo populations, who would eat raw fruits as well 140 as cooked fish; Vespucci's Indians would eat raw herbs and cooked meat, as they would cook strange animals that were looking like snakes (Vespucci, 2013: 145): see also the story narrated by Claude Lévi-Strauss (1964: 102 - 103):

"The fishing by the Bororo is a competition between men and women: as men could not catch any fish, women went fishing and got help from an otter; they were returning home with a lot of fish; men decided to take their revenge: they spied the women by the help of a bird, and they strangled all the otters; also the women took revenge by offering these men some hot drink made with piqui fruits."

As in Lévi-Strauss, one sees binary oppositions between men and women and hot and cold objects; animals are assistants to human beings, and fruits are nutrional resources. Some hot drink serves as some dangerous liquid in places where revenges exist between Indians. Therefore, the contrast between "being raw and cooked" is associated with the binary opposition between "nature and culture," since civilized people prefer cooked food to that raw one (Bullard, 1974: 74). The South Americans were aware of honey and tobacco before the Europeans (Lévi-Strauss, 1966: 13). Animals may eat raw food, whereas humans cooked food (Lévi-Strauss, 1966: 15). According to the Bororo myth, fruits appear as raw nutrional resources versus fish to be cooked before being eaten (Lévi-Struss, 1964: 102 - 103). Some North American Indians practiced "individual totemism" during which a person would try to make peace with the nature (Lévi-Strauss, 1991: 17). Indians respected the nature for being the main resource for their survival; as did Vespucci (2013: 111) narrate to Lorenzo di Pierfrancesco dei Medici in 1502 from Lisbon, underlining that Indians did not have neither laws nor regulations for living "according to the nature," they would eat their meals, sitting on the land, these meals consisted of roots of herbs, fruits, sea products among which one could cite fish, sea urchins, crabs, oysters, shrimps, et cetera. Lévi-Strauss agreed with what Vespucci told by explaining that Indians had no laws as polygamy was acceptable among the Klamath tribe whose members got married to those whom they had met during family visits in exchange of gifts (Lévi-Strauss, 1971): Klamath people were commercial warriors, and were exchanging slaves and products for horses, whereas Modocs had civil chiefs and war chiefs as their governors (Lévi-Strauss, 1971). However, Vespucci (2013: 140) defended that Indians had not appreciated any commercial goods, and they had not got any 
governors, women were better at swimming than men as in Lévi-Strauss's story on fishing, they were taking revenge of previous events in wars, they had no kings, when a person had killed another, the oldest person in the tribe delivered a revenge speech, inviting others to take the revenge of the murder; however, there were not any judges to punish culpable people among the Indians. Amerigo Vespucci depicted all of the above in a letter he wrote to Pier Soderini on September 4, 1504 from Lisbon.

Consequently, both Claude Lévi-Strauss and Amerigo Vespucci referred to binary oppositions, such as 'male-female' and 'raw-cooked' in their descriptions of the populations in South America regardless of the different centuries in which they lived.

\section{2. Nakedness and Primitiveness: Rich-Poor and Uneducated-Educated}

Vespucci believed that the South American populations were primitive enough to be naked, by leading to two binary oppositions: 'rich-poor' and 'uneducated-educated.' The Indians' lands were rich, but they did not have any technological equipment to raise crops, trade gold, or establish farms where they could raise cattles; thus, he wrote a letter to Pier Soderini from Lisbon on September 4, 1504 and titled it "The New World" by saying that the Indians were afraid of the Europeans, since the Europeans had clothes (Vespucci, 2013: 138). These Indians appreciated bells, mirrors, belts, and many other small objects that had no financial value according to the Europeans, trying to discover new trade routes; after having seen some Indian women and children, Vespucci and his peers got astonished on this same land of the Canary Islands (Vespucci, 2013: 139).

Moreover, Vespucci (2013: 152) saw that many Indians had prepared many young men as meals by castrating them, and on his way, he witnessed that there were "about 400 men and numerous women" and tried to pass them to his and his friends' ship through a canoé, but these people escaped; this act was primitive for him. In fact, he was aiming at formulating a way of excuse for using and trading the natural resources of the populations of the lands he had discovered.

Furthermore, after having left these cannibal populations who would eat human meat, Amerigo Vespucci met friendly people, and thought that the people had exchanged onehundredfifty pearls for a small amount of gold, as commerce was a symbol of development and welfare for Vespucci, who also said, "additionally, we saw that they would drink wine made with fruits and seeds from which they make beer" (Vespucci, 2013: 153). Thus, Indians were rich, but in contrast to this richness, they were so naked to be regarded as shameless (Vespucci, 2013: 139): here are the oppositions between the adjectives of rich and poor and uneducated and educated; as Europeans were educated, they covered their bodies with clothes and they had instructors who had taught them geography and commerce alongside good morals (Fernández-Armesto, 2007: 44 - 48). Italians had the ideology for going to the West, whereas the markets of the Iberia were famous: Spanish wool was purchased by Florentines (Fernández-Armesto, 2007: 44). Art trade was common in Europe (Fernández-Armesto, 2007: 45). Seville was full of artistic opportunities (Fernández-Armesto, 2007:46). Olive oil, textiles, raw wool, wine, cereals, cattle, pork products, fish, ironworks, soap, and Canarian sugar were exported to other countries from Spain (Fernández-Armesto, 2007: 47). Seville tried to obtain fish from the Atlantic, took gold and slaves from Sub-Saharan regions, leather from Maghrib, and sugar from Sus (Fernández-Armesto, 2007: 48). Moreover, humanists would study geography: Strabo's Geography, a scientific heritage from the first century B.C. was studied (Fernández-Armesto, 2007: 22). Above all, Ptolemy's Geography had been used in Greek and cosmography lessons since approximately 1397 (Fernández-Armesto, 2007: 21). Meanwhile, Indians were much too primitive to be naked everywhere for Vespucci (2013: 139).

Additionally, Claude Lévi-Strauss showed that the tribe of Caduveo had women with painted faces (LéviStrauss, 1961, pictures 4 -9), and a girl whose whole body was also painted for a puberty rite (Lévi-Strauss, 1961, picture 10). According to Lévi-Strauss (1961: 156), "elaborate designs were painted on her shoulders, arms, and face, and all the necklaces that they could lay hands on were heaped round her neck" for this puberty celebration. He also took a picture of a naked Bororo couple (Lévi-Strauss, 1961, picture 12); he also alluded to the multiple wives of chiefs, such as Kunhatsin, the chief wife of Taperahi (Lévi-Strauss, 1961, picture 59). One conceives that Amerigo Vespucci (2013: 110 - 111) was right, since he defended that the Indians were naked and polygamous in his letter to Lorenzo di Pierfrancesco dei Medici from Lisbon in 1502 by saying that the Indians were "reasonable animals," they saw that populations living in these South American lands were "completely naked" and had neither laws nor religious beliefs, men were putting bones and stones as ornaments to their piercings for seeming wilder, and men were getting married to many women.

www.idildergisi.com 
Consequently, both Europeans and Indians were rich: Europeans had the financial resources, whereas Indians had mines and natural nutritional resources; however, these rich Indians did not have any money; for this reason, they were poor enough not to be able to get education and training from instructors who might have taught them geography and commerce, whereas Europeans were trained about both social sciences alongside good morals. The Europeans were educated, whereas the Indians were uneducated, as they had neither laws nor religious beliefs. Amerigo Vespucci referred to these binary oppositions of 'rich-poor' and 'uneducated-educated,' but Claude Lévi-Strauss admitted that Europeans ruined the natural resources of these lands, impoverishing Indians by the uses of their technological tools that could be purchased by the rich and the educated so that nobody could be harmed, but the natural heritage of the Indians could be devastated, as in Brazil:

“The road from Santos to São Paulo runs through one of the first territories to be exploited by the colonists. It has, therefore, the air of an archaeological site in which a vanished agriculture may be studied. Once-wooded hills offer their bone-structure for our inspection with, at most, a thin covering of sickly grass upon it. We can make out here and there earthworks which mark where a coffee-plantation once stood; they jut out like atrophied breasts through the grassy embankments. In the valleys the region has, as it were, gone back to Nature; but not to the noble architecture of the primeval forest. The capoeira, or secondary forest, is a mere wretched entanglement of half-hearted trees" (Lévi-Strauss, 1961: 98).

Moreover, Indians still believed that one could become ill due to evil spirits without any scientific evidence (Lévi-Strauss, 1961: 156). Besides, some women got married to men out of their tribes, but some had moral confusions: women would give birth to children, being confused about their physical roles, and the husbands who regarded their wives as food providers could easily get confused morally (Lévi-Strauss, 1968).

Therefore, Indians were regarded as poor human beings for not knowing anything about sciences and their moral duties as parents both by Vespucci in the early sixteenth century and Claude Lévi-Strauss in the twentieth century. However, Europeans were rich enough to have technological tools to gather information about them again both for Vespucci, who got on some developed ships to sail and discover the Indians, and Lévi-Strauss, who could photograph the Indians for documenting their external aspects. Europeans were educated enough to wear clothes, but Indians were uneducated enough to be naked everywhere by lacking several moral values that Europeans, who had laws and a religion, had.

\section{3. War Affairs: Primitive-Developed, Strong- Weak, and Shameful-Shameless}

Amerigo Vespucci criticized the populations of the lands he discovered for being violent and primitive in his letter to Lorenzo di Piefrancesco dei Medici from Lisbon in 1502, mentioning the Italian humanist poet Petrarch (Rerum vulgarium fragmenta, XXVIII, 60 as cited by Perini in Vespucci, 2013: 112):

"Furthermore, they are belligerent people, and they are cruel between themselves; besides, all of their arms and blows are against the wind, as does Petrarch say; they consist of bows, arrows, spears, and stones; on a side note, they do not carry any shields for protecting their bodies, because they walk around naked, as if they had come from their mothers' wombs" (Vespucci, 2013: 112 , my translation).

In addition to that, Vespucci (2013: 112) wrote that these populations would eat their enemies and fight cruelly. They would use the teeth of animals and wood pieces in place of metals for making arms (Vespucci, 2013: 140): Vespucci wrote this in his letter to Pier Soderini from Lisbon on September 4, 1504.

Besides, these populations would never punish criminals or naughty children: "They do not employ justice, or they do not punish those who commit crimes: neither the father nor the mother punishes their offsprings" (Vespucci, 2013: 140). Amerigo Vespucci (2013: 149 ) indicated that the proportions of the bodies of Indians alluded to their peculiarities as warriors, and the signs painted on their faces and feathers referred to their strong wills to fight. As well, Claude Lévi-Strauss talked about similar facial paintings based on some cultural experiences of Indians; plus, archeological evidence suggested that the inhabitants of the Americas had a unique curvilinear style before the arrival of Columbus and Vespucci there:

"They did undoubtedly appropriate certain themes: we know of more than, one example of this. In 1857, when a warship, tlie Mwrnanha, made its first appearance on the Paraguay a party of Indians paid her a visit; and on the following day they were seen to have drawn anchors all over their bodies ... This only proves 
that die Mbaya were already habitual and accomplished painters. Their curvilinear style has few counterparts in pre-Colombian America, but it offers analogies with archaeological documents which have been discovered in more than one part of the continent: and some of these pre-date the discovery by several centuries" (LéviStrauss, 1961: 172).

The Indians might have assumed the Renaissance art they had learned from the Europeans (Lévi-Strauss, 1961: 173). Additionally, the people of the Bororo tribe believed that their existence as human beings were "transitory" (Lévi-Strauss, 1961: 219). However, some Indians invented hammocks due to their poverty, but modern people use them in the gardens of luxury hotels today; moreover, nakedness was a symbol of a pure nature for Lévi-Strauss (1961: 268): "The Indians of tropical America invented the hammock. Not to know of the hammock, and not to have any convenience of that kind for rest or sleep, is for them the very symbol of poverty. The Nambikwara sleep naked on the bare earth" (LéviStrauss, 1961: 268)

Thus, regarding the binary oppositions of 'primitive-developed,' 'strong-weak,' and 'shameful-shameless,' the Indians were primitive due to poverty linked to the lack of instruction and education, whereas Europeans were well-developed; the Indians were stronger than the Europeans who were weaker in terms of their body proportions for manual hard work; the Indians were shameless due to poverty again, as they lacked clothes; nor did they have the technological tools necessary for making certain clothes, and Europeans who could get ashamed for being naked were well-developed: they could stitch for being good at sewing and embroidery. For the advanced technological tools, they had, the Europeans could invade the lands of the Indians for using their natural resources, since this was also justified by Amerigo Vespucci, who criticized the cannibalism of Indians for justifying the conquest of their lands by the Europeans.

\section{Conclusion}

To conclude, both Amerigo Vespucci and Claude Lévi-Strauss visited South America. They saw that Indians were living there. Amerigo Vespucci was aiming at discovering new trade routes and objects to trade: for this reason, he had to invent an excuse for exploiting the natural resources of the lands belonging to Indians, and consequently, he proposed that Indians were cannibals. Besides, he argued that Europeans were civilized, educated, and developed, whereas Indians were unciv- ilized, uneducated, and primitive: they did not know anything about navigation, geography, or quality meals that did not involve cooked human meat.

Similarly, Claude Lévi-Strauss showed that Indians were almost as naked as those depicted by Vespucci to be shameless enough to walk around naked, they ate cooked fish and raw fruits, and were living in harmony with the nature without looking for international trade roots. Thus, both Vespucci and Lévi-Strauss posited that the Indians had healthy lives, herbal cures, and hot and cold meals, they were rich in natural resources, but poor in external financial gains, as they did not receive any commercial training; moreover, according to Vespuc$\mathrm{ci}$, the Indians were not monotheistic believers in God, and for this reason, they were uneducated, whereas the Europeans were educated enough to have some morals and manners. Regarding war affairs, for Vespucci, both Indian men and women were strong, women could swim better than men, but they had primitive arms in opposition to the developed ones of the Europeans, strong Indians were athletic, whereas those weak ones were ill enough to wait for natural cures, and all the Indians were shameless enough to be naked most of the time, while the Europeans had covered themselves with fashionable clothes. Vespucci did not have any cameras, but Lévi-Strauss took the photos of the Indians, still living in South America in the twentieth century after the discovery of their ancestors by Vespucci in the early sixteenth century. In this case, the binary oppositions existed between the Indians and the Europeans, whose life styles were distinct in terms of structural anthropology from a Gestalt-like perspective, as both Indians and Europeans formed parts of the entire world for being human beings with different traditions, languages, and cultural practices: members of both groups of people must have exchanged some knowledge about natural cures, resources, and trade, since they could reach an agreement and collaborate for being useful to the entire world without harming the nature.

Human beings that become citizens of a country acquire the culture of that country in contrast to what the nature, i.e., their genetic qualities offer them: there were laws and regulations based on the European culture in the sixteenth and twentieth centuries, but the human nature had to encode the experience and testimonies related to these cultural elements so well that the human beings could learn to control their attitudes and behavior. Amerigo Vespucci should be regarded as a navigator, trying to find new natural items to trade in Europe, inventing the excuse that Indians were can-

www.idildergisi.com 
nibals in order to exploit the nature rather than to analyze and understand the social structures of the Indians. However, Claude Lévi-Strauss is an anthropologist, trying to decipher the traditions of the Indians without accusing them for being polygamous, cannibals, and naked by considering their marriage rules, social organizations, and kinship systems (Lévi-Strauss, 1963: 76). Lévi-Strauss (1963: 370) suggested that social anthropology should have been studied with "economic and social history, social psychology, and linguistics," whereas "cultural anthropology, with technology, geography, and prehistory." Therefore, the observations of Amerigo Vespucci and Claude Lévi-Strauss about South American Indians complete one another from a socio-cultural environmental anthropological point of view.

\section{REFERENCES}

AGİŞ, Fazıla Derya. "Peace Education, Environmentalism, and Amerigo Vespucci". İdil 6.38 (2017): 2673-2684

“Amerigo Vespucci." Biography.com, A\&E Television Networks, LLC., 27 Apr. 2017, www.biography. com/ people/ amerigo-vespucci-9517978.

BRIGGS, Rachel, and Janelle MEYER. "Structuralism." Anthropological Theories: A Guide Prepared by Students for Students, The University of Alabama, Department of Anthropology, 2009. http:/ / anthropology. ua.edu / cultures / cultures.php?culture=structuralism.

BULLARD, Eddie. "Review of: From Honey to Ashes: Introduction to a Science of Mythology, Volume 2, by Claude Levi-Strauss." Folklore Forum 7.1 (1974):7375 .

FERNÁNDEZ-ARMESTO, Felipe. Amerigo: The man who gave his name to America. New York: Random House, 2007.

LÉVI-STRAUSS, Claude. Tristes Tropiques: an anthropological study of primitive societies in Brazil. Translator: John Russell. Criterion: New York, 1961. (Translation first published by: Hutchinson \& Co. (Publishers) Ltd., London, 1961).

LÉVI-STRAUSS, Claude, Structural Anthropology. Translators Claire Jacobson, and Brooke G. Schoepf. New York: Basic Books, 1963.

LÉVI-STRAUSS, Claude. Mythologiques. Le cru 